\title{
VITAMIN D AND BREAST CANCER
}

I. Kostoglou-Athanassiou, E. Papageorgiou, A. Armakolas, M. Koutsilieris

Department of Endocrinology, Red Cross Hospital, Athens, Greece

Department of Experimental Physiology, Medical School, University of Athens, Greece

\section{OBJECTIVES}

The anticancer action of vitamin $D$ is currently considered one of its main properties. The main actions of vitamin $D$ are related to the regulation of calcium levels and the normal function of the musculoskeletal system. However, its anticancer action is currently in

the focus of research interests.

The aim was to study the effect of vitamin D on MCF-7 human breast cancer cells in vitro.

\section{METHODS}

The effect of 1,25(OH)2D3 (Sigma-Aldrich) at an initial concentration of $200 \mathrm{nM}$ on MCF-7 human breast cancer cells was studied in vitro. MCF-7 human breast cancer cells were incubated for $48 \mathrm{~h}$ at a temperature of 370C with progressively decreasing concentrations of $1,25(\mathrm{OH}) 2 \mathrm{D} 3$. MCF-7 cells were also incubated with progressively decreasing concentrations of $1,25(\mathrm{OH}) 2 \mathrm{D} 3$ (the initial concentration of $1,25(\mathrm{OH}) 2 \mathrm{D} 3$ being $200 \mathrm{nM}$ ) in the presence of the antimitotic agent docetaxel $50 \mathrm{nM}$.
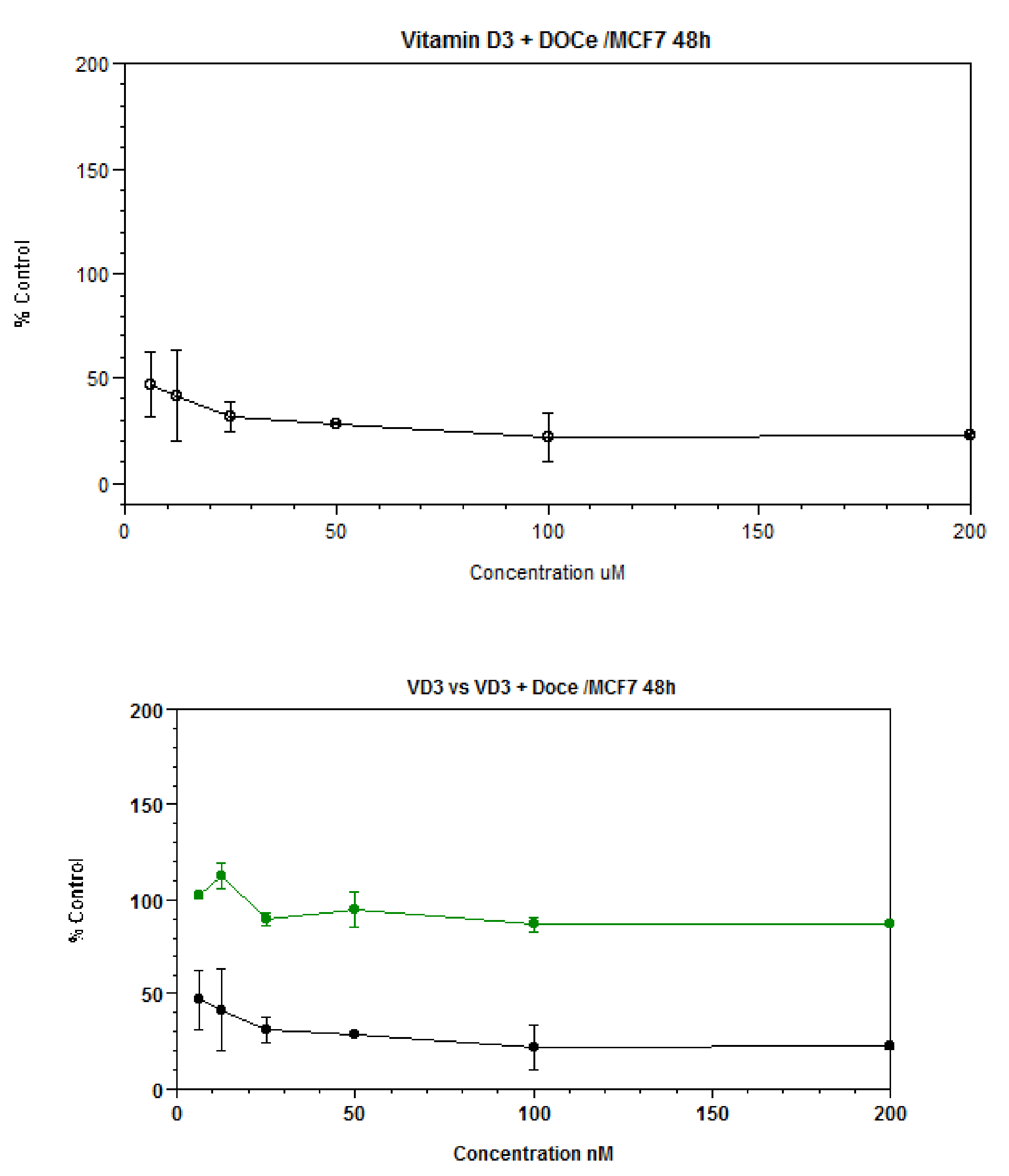

\section{RESULTS}

A mild inhibition of the proliferation of human breast cancer cells MCF- 7 was observed after $48 \mathrm{~h}$ incubation with $1,25(\mathrm{OH})_{2} \mathrm{D}_{3}$. After simultaneous incubation with $1,25(\mathrm{OH})_{2} \mathrm{D}_{3}$ and docetaxel intense inhibition of the proliferation of MCF-7 breast cancer cells was observed.

\section{CONCLUSIONS}

In conclusion, a mild inhibitory effect of $1,25(\mathrm{OH})_{2} \mathrm{D}_{3}$ on the proliferation of MCF-7 human breast cancer cells was observed, while the antimitotic agent docetaxel had intense inhibitory effect on their proliferation. These findings are in agreement with the expression of VDR (Alimirah et al, Mol Cell Biochem 2010), the vitamin D receptor, in breast cancer cells.

\section{References}

Alimirah F, Vaishnav A, McCormick M, Echchgadda I, Chatterjee B, Mehta RG, Peng $X$. Functionality of unliganded VDR in breast cancer cells: repressive action on CYP24 basal transcription. Mol Cell Biochem 2010; 342(1-2):143-50 